\title{
Fungal Secretome for Biorefinery: Recent Advances in Proteomic Technology
}

\author{
Sunil S. Adav* and Siu Kwan Sze* \\ School of Biological Sciences, Nanyang Technological University, Singapore 637551, Singapore
}

Received March 3, 2013; Revised March 20, 2013; Accepted March 21, 2013

First published on the web March 29, 2013; DOI: 10.5478/MSL.2013.4.1.1

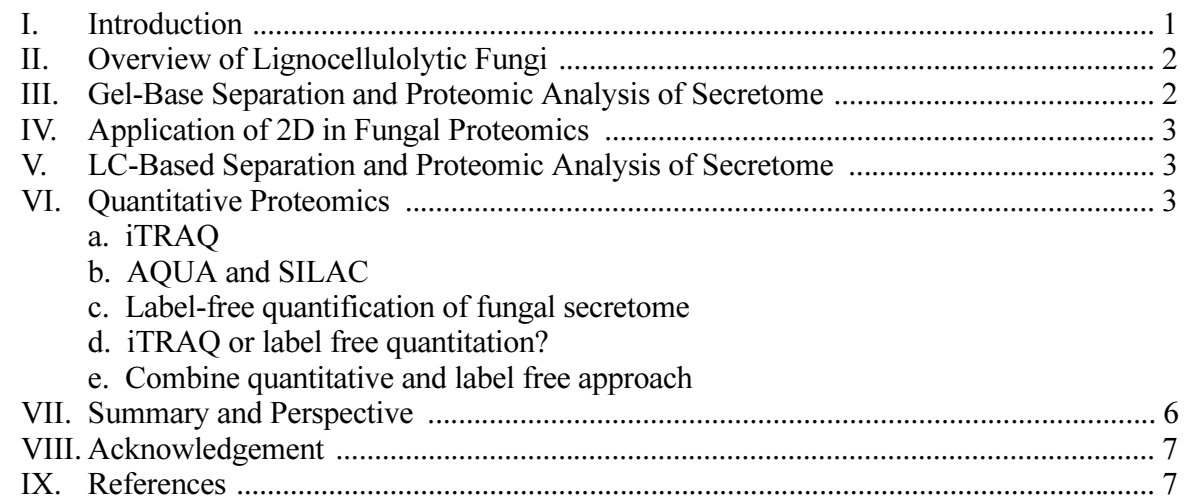

\begin{abstract}
Fungal biotechnology has been well established in food and healthcare sector, and now being explored for lignocellulosic biorefinery due to their great potential to produce a wide array of extracellular enzymes for nutrient recycling. Due to global warming, environmental pollution, green house gases emission and depleting fossil fuel, fungal enzymes for lignocellulosic biomass refinery become a major focus for utilizing renewal bioresources. Proteomic technologies tender better biological understanding and exposition of cellular mechanism of cell or microbes under particular physiological condition and are very useful in characterizing fungal secretome. Hence, in addition to traditional colorimetric enzyme assay, mass-spectrometry-based quantification methods for profiling lignocellulolytic enzymes have gained increasing popularity over the past five years. Majority of these methods include two dimensional gel electrophoresis coupled to mass spectrometry, differential stable isotope labeling and label free quantitation. Therefore, in this review, we reviewed more commonly used different proteomic techniques for profiling fungal secretome with a major focus on two dimensional gel electrophoresis, liquid chromatography-based quantitative mass spectrometry for global protein identification and quantification. We also discussed weaknesses and strengths of these methodologies for comprehensive identification and quantification of extracellular proteome.
\end{abstract}

Key words: Proteomics, LC-MS/MS, Fungal Secretome, Biorefinery, Lignocellulosic biomass

\section{Introduction}

Expressions of particular genes in microbial strain or community during utilization of different carbon sources involve a complex genetic network and differ with type and complexity of carbon sources. Such network can be studied by applying transcriptional profiling (gene expression), proteomics profiling (protein expressions) and metabolomics (metabolite mapping). The importance of fungi in providing the foundation for our understanding of cell cycle, secretion mechanism, mitochondrial evolution, cellular pathways, and many more critical biological processes made us to

* Reprint requests to Dr. Sunil S. Adav and Dr. Siu Kwan Sze E-mail: ssadav@ntu.edu.sg and sksze@ntu.edu.sg sequence several fungal genomes; while issues like global warming, environmental pollution, green house gases emission, depleting fossil fuel has made us to focus on renewable bioresources, such as the use of fungal secretome for lignocellulosic biorefinery. Again, the non-food feedstock such as agricultural residues (e.g., corn stover, sugarcane bagasse, husks, rice and wheat straws, barley straws etc.), agricultural processing byproducts (e.g., corn fiber, sugarcane bagasse, seed cake, etc.), energy crops (e.g., switch grass, poplar, banagrass, miscanthus, etc.), hardwood, softwood, cellulosic waste, forest waste and municipal solid wastes are abundant renewable biomasses that can serve as a major substrate for lignocellulosic biorefinery and bioenergy. Thus, genomes of well known lignocellulose degrading fungi belonging to Ascomycota (Neurospora crassa, Aspergillus 
aculeatus, Aspergillus nidulans, Aspergillus niger, Aspergillus oryzae, Penicillium chrysogenum, Trichoderma atroviride, Trichoderma reesei, Trichoderma virens, and many more) and Basidiomycota (Pleurotus ostreatus, Postia placenta, Phanerochaete chrysosporium etc,) have been sequenced and made available for public. ${ }^{1-8}$

Fungi digest or degrade complex substrates outside the cell before their intake and hence they secrete large number of extracellular hydrolytic enzymes, generally arbitrated as secretome. The secretome includes all secreted proteins, either anchored to cell surface or in the extracellular environment and also the proteins involved in secretory pathway. These secretory enzymes have been investigated from different point of views or due to their biotechnological applications. ${ }^{9}$ Traditionally, colorimetric methods were used for quantitative analysis of extracellular secreted enzymes. However, these methods when evaluated based on their limitations such as range, sensitivity, specificity, ease of conducting assay, ability to detect isoforms, reagent crossreactivity, and inability to quantify each constituent protein of complex secretome emphasized development of alternative methods.

Extensive advances in technology, emergence of genomics, proteomics and protein-tagging technology made it possible to determine the complex composition of the secretome. Proteomics provides a global view of the protein expressed during biomass degradation process and, in combination with other omics technologies, has potential to uncover biomass degradation mechanism, and thereby advance the development in designing of enzyme cocktail for efficient biomass hydrolysis. To degrade biomass, fungi secrete vast number of extracellular enzymes hence secretome related studies could be more relevant in understanding underlying biomass degradation. Therefore, this review paper provides an up-to-date review on recent developments on proteomic techniques used to study lignocellulolytic enzymes and biochemical route that fungi use to degrade plant biomass; and attempts to shed light on the fundamental understanding in lignocellulosic biomass hydrolysis.

\section{Overview of Lignocellulolytic Fungi}

Fungal biotechnology has already established societal benefits by bringing innovative and valuable healthcare and food products to market. Despite progress in green chemistry and proven contribution of fungi in recycling lignocellulosic biomass, production and commercialization of commodity products such as chemicals, fuels or electricity from lignocellulosic wastes is still lagging. The recycling of photosynthetically fixed carbon by microbe, particularly, by fungi is fundamental biological process and integral part of biogeochemical cycle. Fungi degrade biomass via different mechanism and differ in the way they make cellulose, hemicelluloses accessible to enzymes. Based on the morphology arising from the attack (white or brown pockets) they are broadly divided into white rot, brown rot and soft rot. Two distinguishable patterns of biomass delignification such as simultaneous delignification and selective delignification have been documented. ${ }^{7}$ White rot fungi are numerous and include members of both ascomycota and basidiomycota. These white rot fungi have potential to completely degrade lignocellulosic biomass since they are capable to degrade lignin by cleaving bonds between $\mathrm{C} \alpha$ and $\mathrm{C} \beta$. While, brown rot prevalently attack on coniferous wood, removes cellulose and hemicellulose and can not degrade lignin or degrade only small part. Thus, both white and brown rot are very specific trait of basidiomycetes. Fungi like $P$. chrysosporium, Trametes versicolor, Irpex lacteus, Heterobasidion annosum, Phlebia radiate, Xylaria hypoxylon and many others have been evolved with simultaneous delignification potential and hence can degrade biomass completely. Brown rot fungi including Schizophyllum commune, Postia placenta, Fomes fomentarius, Serpula lacrymans first removes cellulose and hemicellulose and demethylate lignin. Removal of cellulose or breakdown of bonds between cellulose molecules causes loss in mechanical strength of biomass or wood. The soft rot is a typical feature of ascomycetes that neither attack middle lamina nor involve ligninases.

Lignin removal opens the way for wood colonization by other microbial populations which is a key step for the recycling of carbon. Lignin degradation is an oxidative process where fungal extracellular peroxidases and oxidases (glyoxal oxidase, pyranose-2 oxidase, and aryl-alcohol oxidase) oxidizes the polymer. Enzymes such as lignin peroxidase $(\mathrm{LiP})$, manganese peroxidase $(\mathrm{MnP})$ and versatile peroxidase (VP) by P. chrysosporium play major role in lignin oxidation and remain true landmarks in the field of enzymatic delignication. ${ }^{10}$ In addition, some white-rot basidiomycetes and some other fungi produce multicopper oxidases called laccase, that oxidizes lignin and other recalcitrant compounds in the presence of a redox mediators. ${ }^{11,12}$ T. reesei, Pichia stipitis, and P. chrysosporium have been initially identified as important fungi in biotechnological transformation of cellulose, hemicellulose, and lignin, respectively. ${ }^{6-8,13}$ There are several documentary literature of laccase production by ascomycetes and they were purified from phytopathogenic ascomycetes such as Gaeumannomyces graminis, ${ }^{14}$ Magnaporthe grisea ${ }^{15}$ Ophiostomanovo-ulmi ${ }^{16}$ Mauginella sp., ${ }^{17}$ Melanocarpus albomyces, ${ }^{18}$ Monocillium indicum, ${ }^{19}$ N. crassa,${ }^{20}$ Podospora anserine and many more. The occurrences of laccase in the natural environment, their significance, characteristics, unique properties and biotechnological applications have been reviewed by Baldrian. ${ }^{11}$

\section{Gel-Base Separation and Proteomic Analysis of Secretome}

Protein separation techniques including gel electrophoresis 
or chromatographic separation prior to mass spectrometry analysis play major role in proteomics. Polyacrylamide gel electrophoresis (PAGE) separation technique is used as a preparatory technique for separation or purification of proteins prior to identification by MALDI-TOF or LC-MS/ MS analysis, while chromatographic methods have been coupled with MS using both on-line and off-line separation steps. Gel electrophoresis differentiates molecular entities depending on their physical characteristics such as size, shape, charge and isoelectric point. Two-dimensional PAGE (2D-PAGE), a classical proteomic technique that separates proteins by isoelectric point and molecular weight, remain as a well established technique in proteomic analysis of complex samples. The general work flow involves protein separation by $2 \mathrm{D}$ gel, protein visualization by staining, gel image analysis, protein spot excision, tryptic digestion, analysis of the peptide mass, database search and further validation. $^{21}$

\section{Application of 2D in Fungal Proteomics}

Due to potential to promote economical and environmental friendly sustainable energy production, plant feedstocks are at the forefront of the biofuel industry. Several structural and compositional features hinder hydrolysis of lignocellulosic cellulose to sugars and other organic compounds and hence several physical, chemical and enzymatic pretreatments have been tested. The advantages of enzymatic pretreatment and its environmental friendly nature attracted more research on fungal lignocellulolytic enzymes. Using most popular 2D electrophoresis (2DE) technique and mass spectrometry as the core tool, extracellular proteins of $A$. oryzae in submerged and solidstate cultures with wheat bran as a substrate have been compared. $^{22}$ Lignocellulolytic enzymes of Penicillium echinulatum using sugarcane bagasse, microcrystalline cellulose and pretreated sugarcane bagasse have been profiled. ${ }^{23}$ Again, using sugarcane as a substrate, expression of lignocellulolytic enzymes of Ganoderma lucidum revealed several cellulases, hemicellulases, cellobiose dehydrogenase, glycoside hydrolases, $\mathrm{MnP}$, laccases, glutathione reductases and demonstrated G. lucidum as a potential candidate for lignocellulose biomass hydrolysis and subsequently for lignocellulosic biorefinery. ${ }^{24}$ The secretome of Pleurotus sapidus from submerged cultures either on peanut shells or on glass wool revealed wide spectrum of secreted enzymes including various types of hydrolases and lignin degrading manganese peroxidase/versatile peroxidases. ${ }^{25}$ Lignocellulose rich material such as banana pseudostems, wheat straw or coffee pulp also served as starting materials for exploring lignocellulolytic enzymes of two Pleurotus species and six Lentinula edodes strains. ${ }^{26,27}$

Using 2DE, Hori and coworkers ${ }^{28}$ investigated the effects of xylan and starch on protein secretion by the basidiomycete P. chrysosporium grown on cellulose and found that xylan increases synthesis of several glycoside hydrolase, putative endoxylanases and a putative glucuronyl esterase belonging to carbohydrate esterase family 15 . In addition to these enzymes, cellobiose dehydrogenase and GH family 61 proteins were also increased in the presence of xylan. 2DE analysis of secretome by $P$. chrysosporium from liquid culture condition containing glucose, cellulose or wood chips as the carbon source revealed presence of enzymes involved in cellulose, hemicellulose, lignin and protein degradation. ${ }^{29}$ Vanden Wymelenberg et al. ${ }^{30}$ analyzed $P$. chrysosporium genome with PHOBIUS predictive software and initiated mass spectrometric identifications of proteins in cellulose-grown medium. The multiple endoglucanase and exocellobiohydrolase isozymes (CBH) of $P$. chrysosporium were identified, purified and named as $\mathrm{CBH} 62, \mathrm{CBH} 58$, and CBH50. ${ }^{31-33}$ Genetic analysis identified corresponding genes i.e., cel7C, cel7D, and cel6A and became the inputs for molecular modeling study.

\section{LC-Based Separation and Proteomic Analysis of Secretome}

For comprehensive identification of proteins, mostly, a peptide-centric approach is adopted where proteins are trypsin digested, and then components of the peptide mixture are separated by using liquid chromatography prior to its MS analysis. Such LC-based proteomics techniques are much more important to produce unambiguous protein identification since samples contain thousands of proteins and its tryptic digestion results hundreds of thousands of peptides. Electrostatic repulsion hydrophilic interaction chromatography (ERLIC) has been developed and further compared with SCX. ${ }^{34-36}$ Further, Adav et al. ${ }^{37-40}$ applied this ERLIC technique to study secretome of the lignocellulolytic fungi with a particular objective to explore expression of lignocellulolytic enzymes for biorefinery.

\section{Quantitative Proteomics}

The accurate protein quantitation is currently one of the most challenging and rapidly changing areas of proteomics. The choice of methods for quantitative proteomics depends on multiple factors including the source of the samples, the number of samples, the number of treatments being compared, the type of equipment available, time requirement and most importantly expenses. Several quantitation methods including isotope labeling approaches like Isotope-Coded Afffinity Tag (ICAT), Stable Isotope Labeling by Amino Acids in Cell Culture (SILAC), ${ }^{15} \mathrm{~N} /{ }^{14} \mathrm{~N}$ metabolic labeling, ${ }^{18} \mathrm{O} /{ }^{16} \mathrm{O}$ enzymatic labeling, Isotope Coded Protein Labeling (ICPL), Tandem Mass Tags (TMT), Isobaric Tags for Relative and Absolute Quantication (iTRAQ), and other chemical labeling have been adopted in quantitative proteomics. ${ }^{41,42}$ The majority of the mass spectrometry quantitative methods involves tryptic digestion of proteins and then takes advantage 
of measurements made on peptide level to compute a summarized value for corresponding protein. Such approach can be divided into two categories, one is label free quantitation and other involves use of stable isotopes or isobaric tags. Again, quantitative proteomics can be subcategorized into absolute which estimates changes in protein expression in terms of an exact amount/concentration (i.e., nmoles/mmoles) of each protein present in the given sample; and relative quantitation that determines fold change (up- or down-regulation) of a protein relative to control.

\section{iTRAQ}

The iTRAQ technology utilizes isobaric reagents to label the primary amines of peptides and proteins and widely used in discovery-based proteomics. Due to multiplexing reagent designing, iTRAQ allows multiplexing of four to eight different samples in a single MS experiment. ${ }^{43,44}$ During iTRAQ-labeling isobaric tags react with amine groups in peptides generated by tryptic digestion and label N-terminal amino group and $\varepsilon$-amino group of lysine residues. Similarly, two different amine reactive versions of tags called tandem mass tags (TMT) are also commercially available. ${ }^{45}$ Since iTRAQ quantitation is at MS/MS level rather than MS level, it gives better results due to lack of chemical noise that interfere quantitation quality at MS1 level. Again, the tags used in iTRAQ reagent are isobaric, the signal in the mass spectrometer is the sum of the peptide contribution from all samples, so there is a gain in sensitivity. ${ }^{43}$

The iTRAQ technique has been applied to profile the quantitative expression of secretory lignocellulolytic enzymes of T. reesei, P. chrysosporium and A. niger. ${ }^{37-40,46}$ The work flow involved in such study is outlined in Figure 1. Using iTRAQ-based proteomics, expression and relative quantitation of $65,37,34$, and 54 cellulolytic, hemicellulolytic, and lignin-degrading proteins and peptidases, respectively by $T$. reesei $\mathrm{QM} 6 \mathrm{a}$ and $T$. reesei Rut $\mathrm{C} 30$ has been reported when strains were cultivated on saw dust. ${ }^{37}$ This iTRAQquantitation approach facilitated quantitation of 84 glycosyl hydrolases (GHs) from $T$. reesei QM6a and Rut C30 during cellulose and lignocelluloses degradation which were significantly higher than those reported in P. chrysosporium, P. sapidus, A. oryzae.

The culturing of $T$. reesei QM6a and Rut C30 fungal strains with saw dust as a major substrate resulted expression and regulation of one each $\mathrm{CBH} 1, \mathrm{CBH} 2, \mathrm{EG} 1$, EG3, EG5; two EG2s and two EG4s. The expression and up-regulation of these enzymes indicated potential of $T$. resse $i$ strain in biomass hydrolysis. On other hand, T. ressei genome encodes one $\mathrm{CBH} 1, \mathrm{CBH} 2, \mathrm{EG} 1, \mathrm{EG} 3$, and EG5; two EG2s; and three EG4s. ${ }^{7}$ It's important to note that genetic comparison of $T$. reesei Rut $\mathrm{C} 30$ and wild strain revealed 223 single nucleotide variants, 15 small deletions or insertions, and 18 large deletions, leading to the loss of more than $100 \mathrm{~kb}$ of genomic DNA in T. reesei Rut C30. ${ }^{47}$ The differential expression of proteins in the secretome of

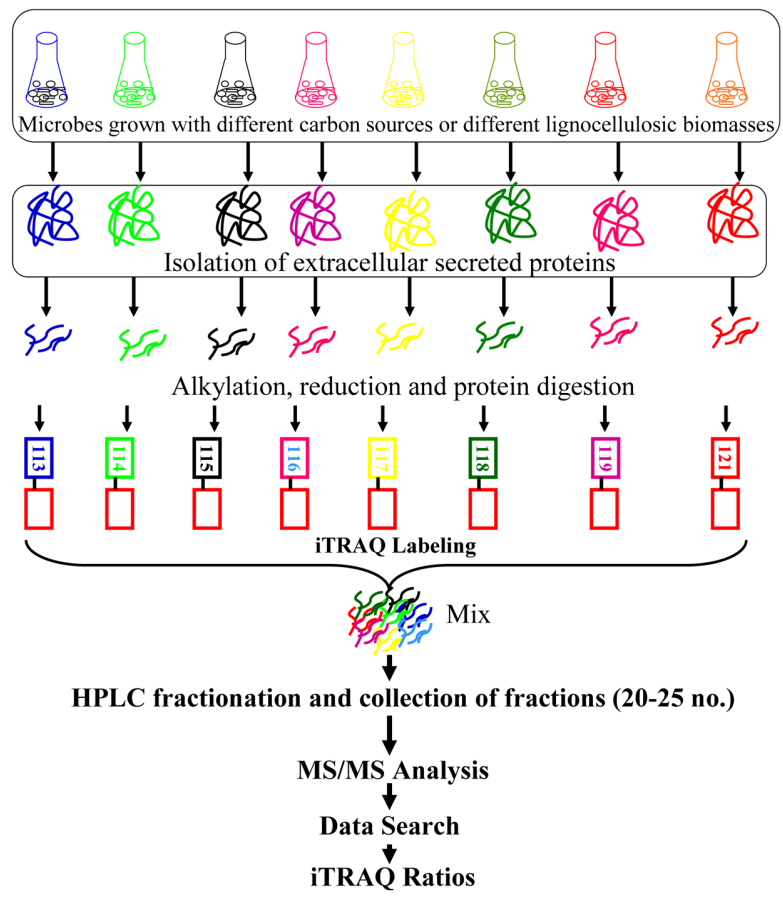

Figure 1. Typical work flow for iTRAQ-based proteomics analysis of fungal secretome.

wild T. reesei QM6a and mutant Rut C30 in response to different lignocellulosic biomasses revealed that the expressions and regulations of these biomass degrading proteins were dependent on both nature and complexity of different lignocellulosic carbon sources.

Manavalan et al. ${ }^{48}$ applied iTRAQ technique to profile expression of lignocellulolytic enzymes of basidiomycete $P$. chrysosporium in cellulosic culture condition and quantified 117 enzymes comprising cellulose hydrolyzing endoglucanases, exoglucanases, beta-glucosidases; hemicelluloses hydrolyzing xylanases, acetylxylan esterases, mannosidases, mannanases; pectin-degrading enzymes polygalacturonase, rhamnogalacturonase, arabinose; and lignin degrading protein belonging to oxidoreductase family. Profiling quantitative expression of lignocellulolytic enzymes on natural lignocellulosic biomass remain essential since biomass structural complexity, degree of lignifications, proportional content of lignin, cellulose, and hemicellulose vary significantly with type and age of agricultural or forest residues. Therefore, secretome of $P$. chrysosporium precultivated with different natural lignocellulosic materials such as corn stover, hay, sawdust, sugarcane baggase, wheat bran and wood chips has been correlated by using iTRAQ quantitation. $^{40}$ The comparison of iTRAQ ratios of enzymes in different lignocellulosic biomass revealed differential expression of lignocellulolytic enzyme including numerous cellulases, glycoside hydrolases, hemicellulases, esterases, lignin degrading enzymes, lipases, peptidases, chitinases, 
protein translocating transporter and hypothetical proteins and explored oxidative and hydrolytic lignin degrading mechanism of $P$. chrysosporium. ${ }^{40} P$. chrysosporium is potent lignin degrading fungal strain and it employs lignin peroxidase ( $\mathrm{LiP}$ ) and manganese peroxidase $(\mathrm{MnP})$ for lignin degradation. However, $\mathrm{LiP}$ and $\mathrm{MnP}$ require $\mathrm{H}_{2} \mathrm{O}_{2}$ for their catalytic activities, and thus copper radical oxidases as well as glyoxal oxidase remain as major donors of $\mathrm{H}_{2} \mathrm{O}_{2}$. Adav et al. ${ }^{40}$ iTRAQ quantified five copper radical oxidases in the secretome of $P$. chrysosporium, while Wymelenberg et al. ${ }^{49}$ identified six copper radical oxidase encoding genes ( $\mathrm{crol}-\mathrm{cro} \sigma)$. Again, based on position of these genes, a strong relationship between peroxidases and copper radical oxidases has been predicted.

Although, iTRAQ technologies have many attractive attributes and widely used in proteomics, but yet this technique have several limitations. Wu et al. ${ }^{50}$ compared cICAT, iTRAQ, and DIGE, and found that ITRAQ was more sensitive for quantitation, but more susceptible to errors in precursor ion isolation, indicating mass spectrometer interference hinders iTRAQ reliability. The issues like iTRAQ-reproducibility and reliability has been addressed by Chee et al. ${ }^{51}$ Minor disadvantages include incomplete labeling since the labeling reaction is $\mathrm{pH}$ dependent. This limitation can be eliminated by checking $\mathrm{pH}$ of the sample solutions before labeling. The major limitations of iTRAQ technologies are its precision, accuracy and reliability. ${ }^{52,43}$ The comparisons of the label free MSE quantification with the iTRAQ quantification using a QTOF instrument recorded divergence in the degree of upregulation of up to a factor of 9.2 between the two quantification methods, with the iTRAQ method giving lower ratios. ${ }^{53}$ Similarly, a discrepancy of underestimation of up to 5 factors was noted when investigating 8-plex iTRAQ reagent with analysis on a QStar XL instrument. ${ }^{54}$ The issues like underestimation of ratios, limited dynamic range (fold changes of $<2$ orders of magnitude are typically reported), high reagent cost and a limitation for ion-trap instruments due to the " $1 / 3^{\text {rd }}$ rule" are critical and their possible solutions are discussed in several reviews. ${ }^{55-61}$ The ambiguity of measurements can be explained at least in part by correlation with reporter ion signal intensity. However, several methods like intensity weighted averaging of multiple spectra of given peptide or protein, post-acquisition filtering of data to exclude low intensity measurements, data normalization and advances in ion transmission hardware may address the issues with accuracy and precision. ${ }^{52,62-64} \mathrm{~A}$ more persistent issue with isobaric tagging is that of accuracy. The most common reason for the accuracy issue is the presence of co-eluting peptides with $\mathrm{m} / \mathrm{z}$ in the precursor ion isolation window.

\section{AQUA and SILAC}

Stable isotope labeling by amino acids in cell culture (SILAC), introduced by Mann and co-workers for highthroughput quantitative proteomic analysis has been used in many different organisms for protein levels quantification. ${ }^{65}$ $N$. crassa secrete complex cocktail of enzymes that completely depolymerize cellulose and other plant cell wall polysaccharides. ${ }^{66}$ Therefore, Phillips et al. ${ }^{67}$ initiated absolute quantication (AQUA) of the N. crassa secretome by selecting candidate proteins to serve as internal standards for LC-MS analysis. It's well known that AQUA can serves as an expedient method to quantify proteins based on a synthetic peptide standard but the major disadvantage is that intact protein can not be quantified based on only single peptide. To validate such quantitation, the general strategy could be mass-differentiated stable isotope labeling of the protein to be compared. Thus, SILIC can be introduced either by growing fungal strain on stable isotope-coded media, typically ammonium or nitrate salts enriched in ${ }^{15} \mathrm{~N}$ as the sole nitrogen source or by supplementing the growth media with stable isotope-coded amino acids. ${ }^{68}$ Using SILAC, Phillips et al. ${ }^{67}$ estimated absolute quantities of cellobiohydrolase I (CBHI), cellobiohydrolase II (CBHII) GH5 endoglucanase and GH3 beta-glucosidase in the secretome of $N$. crassa. Based on these estimated absolute quantities, these authors constituted enzyme cocktail for cellulose degradation. However, reconstituted secretome showed lower cellulose degradation than crude secretome of $N$. crassa suggesting other cellulases or accessory proteins are important for degradation of cellulose by $N$. crassa. Thus, this study challenges the "exo-endo" enzyme model that ascertain requirement of three key enzymes (exoglucanse, endoglucanase and beta-glucosidase) for complete cellulose hydrolysis and encourages us for further detailed cellulose degradation study.

SILAC has been used to study the temperature-dependent expression of whole proteome of $A$. flavus during biosynthesis of aflatoxin. Autotrophic organisms can be labeled metabolically with ${ }^{14} \mathrm{~N} /{ }^{15} \mathrm{~N}$ label using growth media containing $\mathrm{K}^{15} \mathrm{NO}_{3}$ and such approach has been employed for proteome of Saccharomyces cerevisiae. ${ }^{69}$ Yet, proteome can be labeled during proteolytic digestion in the presence of $\mathrm{H}_{2}{ }^{18} \mathrm{O}$ or $\mathrm{H}_{2}{ }^{16} \mathrm{O}$ that generates peptides with mass difference of $4 \mathrm{Da}^{70}$ While chemical stable isotope labeling utilizes isotope-coded affinity tag (ICAT) ${ }^{71}$ that exploits ${ }^{12} \mathrm{C} /{ }^{13} \mathrm{C}$ for isotope coding and an acid-cleavable linker for pair-wise comparison of test samples and estimates relative abundance of cysteinyl-containing peptides. However, these techniques have been rarely used for exploring fungal secretome that can be exploited for lignocellulosic bioenergy.

\section{Label-free quantification of fungal secretome}

Although, stable isotope labeling methods are powerful for accurately determining changes in protein level but suffer from limited dynamic range. Quantitative proteomics with iTRAQ or stable isotope coding requires expensive labeling reagents, large amount of sample proteins and complex labeling procedures that reduces detection 
sensitivity. On the contrary, label free quantitation is free of labeling reagent; applicable to all type of biological samples, can process any number of samples, and can be a rapid protein quantitation techniques. Label free quantitation methods uses Exponentially Modified Protein Abundance Index (emPAI) that offers relative quantitation of the proteins in a mixture based on protein coverage by the peptide matches in a database search result. ${ }^{72}$ The spectral counting method that relies on counting the number of spectra that map to a given protein across multiple LC-MS analyses, peptide peak intensity, the peak area, the height, quantification of the MS signal and average TIC are the other documented approaches under label free quantitation. ${ }^{73}$ By taking advantage of the linear correlations between peak areas and corresponding peptide abundance, Shewanella oneidensis proteome under aerobic and anaerobic grown culture conditions has been profiled. ${ }^{74,75}$ Using label free quantitative technique (i.e., emPAI), secretory proteins of T. fusca with cellulose and different lignocellulosic biomasses as a major carbon source revealed induced production of cellulolytic proteins on cellulosic substrate while lignocellulosic biomass stimulated expressions of hemicellulolytic and lignin degrading proteins. ${ }^{76}$ Further, using label free quantitation, cellulose degrading enzymes of T. reesei QM6a, QM9414, RUT C30 and QM9414MG5 strains at different $\mathrm{pH}$ in cellulosic culture condition has been established and demonstrated higher hydrolytic protein expressions at acidic $\mathrm{pH}^{77}$

\section{iTRAQ or label free quantitation?}

The comparison of iTRAQ and label-free quantitative approaches found that iTRAQ gave $54 \%$ single peptide identifications, while only $0.9 \%$ of the identifications in label-free methods were single peptide hits. ${ }^{53}$ Mostly data with single peptide remain as a low confidence and if all single peptide hits preferred to be excluded during quantifications then the impact on proteome coverage by iTRAQ would be considerable. This study indicated that label free quantitative techniques are better than iTRAQquantitative approach. Again, in a study carried by Phillip Wright group on a cyanobacterium, they found $75 \%$ more proteins by label free method when compared with 4-plex iTRAQ. ${ }^{43}$ Two LC-based quantitative proteomics approaches i.e., iTRAQ and label free were adopted using the LTQ Orbitrap Velos platform for the study of two Chlamydomonas reinhardtii strains ${ }^{57}$. Authors found that both iTRAQ labeling and label-free methods provide high quality quantitative and qualitative data.

\section{Combine quantitative and label free approach}

In lignocellulosic biomass hydrolysis as well as in other biological systems, determination of the exact concentration of proteins and time resolved changes are important to uncover the possible mechanism. Hence, by combining iTRAQ-quantitative and label free quantitative approach, protein abundances in the secretome of individual fungal strains and constructed microbial communities during lignocellulosic biomass hydrolysis have been reported. ${ }^{39}$ By combining quantitative data from ITRAQ and label free emPAI approach, authors determined the abundances of lignocellulolytic proteins in the secretome of $P$. chrysosporium, T. reesei Rut C30, T. reesei $\mathrm{QM6a}$, and $C$. nepalica and also in combinations like $P$. chrysosporium + T. reesei Rut $\mathrm{C} 30$; P. chrysosporium + T. reesei QM6a; $P$. chrysosporium $+C$. nepalica and P. chrysosporium $+T$. reesei $\mathrm{RutC} 30+$ T. reesei $\mathrm{QM} 6 \mathrm{a}+C$. nepalica. While, using a combination of AQUA and absolute SILAC the absolute abundances of the protein in the secretome of $N$. crassa has been estimated. ${ }^{67}$ MRM quantitation is ideal for proteomics and its application for the absolute quantitation (AQUA) of proteins has been introduced by Steven Gygi. ${ }^{78}$ Methods like selected ion monitoring (SIM) or selected reaction monitoring (SRM) may improve the limits of detection for an analyte but rarely applied to study fungal secretome.

\section{Summary and Perspective}

Lignocellulosic biomass comprising cellulose, hemicellulose and lignin is virtually inexhaustible most abundant renewable carbon resource. The enzymatic conversion of cellulosic, forest and agricultural wastes to fermentable sugars can potentially generate significant amounts of bioenergy to mitigate global warming and current global energy crisis. In addition to bioenergy, lignocellulosic biomass deconstruction will produce value added products and chemicals. Application of proteomics in profiling quantitative expressions of extracellular secreted fungal proteins during biomass deconstruction provides a glimpse into lignocellulolytic enzyme action and may divulge promising shift from bioprospecting and novel enzyme discover. Proteomics study of fungal or microbial community secretome highlighting quantitative protein abundances in the secretome would shed light on the designing of microbial enzyme cocktail for biomass hydrolysis. Thus, recent efforts to explore lignocellulolytic protein expression during biomass degradation by different proteomic techniques have been presented. We also propose the following perspectives to the potential development of the proteomic techniques for fungal enzymes analysis and novel fungal enzyme characterization in the near future.

An enthusiasm about the potential application of proteomics to discover enzymatic mechanism of biomass hydrolysis has been tampered by complexity, wide range of variably regulated and dynamic nature of enzymes. We discussed above several proteomics methods including quantitative and label free but yet little work has been done on absolute quantitation of each protein in the fungal secretome. To design efficient biomass degrading enzyme cocktail, absolute quantities of enzymes are very much important, and hence more research work on absolute 
quantitation is required. Majority of published literature highlights only cellulases, hemicellulases and lignin degrading enzymes ignoring other enzymes such as chitinases, proteases, peptidases, transporters etc. Considering complex nature of biomass, quantitative proteomic profiling of whole secretome enzymes, their discussion and interpretation, enzyme synergisms must expand beyond cellulases, hemicellulases and lignin degrading enzymes. Work on isolation of thermoresistant lignocellulolytic fungi, proteomic profiling of such themostable enzymes and novel candidate is warranted.

\section{Acknowledgements}

This work is supported by grants from Nanyang Technological University (RG 157/06, RG 61/06 and RG $51 / 10)$.

\section{References}

1. Galagan, J. E.; Calvo, S. E.; Borkovich, K. A.; Selker, E. U.; Read, N. O.; Jaffe, D.; FitzHugh, W.; Ma, L. J.; Smirnov, S.; Purcell, S.; Rehman, B.; Elkins, T.; Engels, R.; Wang, S.; Nielsen, C. B.; Butler, J.; Endrizzi, M.; Qui, D.; Ianakiev, P.; Bell-Pedersen, D.; Nelson, M. A.; Werner-Washburne, M.; Selitrennikoff, C. P.; Kinsey, J. A.; Braun, E. L.; Zelter, A.; Schulte, U.; Kothe, G. O.; Jedd, G.; Mewes, W.; Staben, C.; Marcotte, E.; Greenberg, D.; Roy, A.; Foley, K.; Naylor, J.; Stange-Thomann, N.; Barrett, R.; Gnerre, S.; Kamal, M.; Kamvysselis, M.; Mauceli, E.; Bielke, C.; Rudd, S.; Frishman, D.; Krystofova, S.; Rasmussen, C.; Metzenberg, R. L.; Perkins, D. D.; Kroken, S.; Cogoni, C.; Macino, G.; Catcheside, D.; Li, W.; Pratt, R. J.; Osmani, S. A.; DeSouza, C. P. C.; Glass, L.; Orbach, M. J.; Berglund, J. A.; Voelker, R.; Yarden, O.; Plamann, M.; Seiler, S.; Dunlap, J.; Radford, A.; Aramayo, R.; Natvig, D. O.; Alex, L. A.; Mannhaupt, G.; Ebbole, D. J.; Freitag, M.; Paulsen, I.; Sachs, M. S.; Lander, E. S.; Nusbaum, C.; Birren, B. Nature 2003, 422, 859.

2. Pel, H. J.; De Winde, J. H.; Archer, D. B.; Dyer, P. S.; Hofmann, G.; Schaap, P. J.; Turner, G.; De Vries, R. P.; Albang, R.; Albermann, K.; Andersen, M. R.; Bendtsen, J. D.; Benen, J. A. E.; Van Den Berg, M.; Breestraat, S.; Caddick, M. X.; Contreras, R.; Cornell, M.; Coutinho, P. M.; Danchin, E. G. J.; Debets, A. J. M.; Dekker, P.; Van Dijck, P. W. M.; Van Dijk, A.; Dijkhuizen, L.; Driessen, A. J. M.; D'Enfert, C.; Geysens, S.; Goosen, C.; Groot, G. S. P.; De Groot, P. W. J.; Guillemette, T.; Henrissat, B.; Herweijer, M.; Van Den Hombergh, J. P. T. W.; Van Den Hondel, C. A. M. J. J.; Van Der Heijden, R. T. J. M.; Van Der Kaaij, R. M.; Klis, F. M.; Kools, H. J.; Kubicek, C. P.; Van Kuyk, P. A.; Lauber, J.; Lu, X.; Van Der Maarel, M. J. E. C.; Meulenberg, R.; Menke, H.; Mortimer, M. A.; Nielsen, J.; Oliver, S. G.; Olsthoorn, M.; Pal, K.; Van Peij, N. N. M. E.; Ram, A. F. J.; Rinas, U.; Roubos, J. A.; Sagt, C. M. J.; Schmoll, M.; Sun, J.; Ussery, D.; Varga, J.;
Vervecken, W.; Van De Vondervoort, P. J. J.; Wedler, H.; Wösten, H. A. B.; Zeng, A. P.; Van Ooyen, A. J. J.; Visser, J.; Stam, H. Nat. Biotechnol. 2007, 25, 221.

3. Galagan, J. E.; Calvo, S. E.; Cuomo, C.; Ma, L. J.; Wortman, J. R.; Batzoglou, S.; Lee, S. I.; Baştürkmen, M.; Spevak, C. C.; Clutterbuck, J.; Kapitonov, V.; Jurka, J.; Scazzocchio, C.; Farman, M.; Butler, J.; Purcell, S.; Harris, S.; Braus, G. H.; Draht, O.; Busch, S.; D'Enfert, C.; Bouchier, C.; Goldman, G. H.; Bell-Pedersen, D.; Griffiths-Jones, S.; Doonan, J. H.; Yu, J.; Vienken, K.; Pain, A.; Freitag, M.; Selker, E. U.; Archer, D. B.; Peñalva, M. Á.; Oakley, B. R.; Momany, M.; Tanaka, T.; Kumagai, T.; Asai, K.; Machida, M.; Nierman, W. C.; Denning, D. W.; Caddick, M.; Hynes, M.; Paoletti, M.; Fischer, R.; Miller, B.; Dyer, P.; Sachs, M. S.; Osmani, S. A.; Birren, B. W. Nature 2005, 438, 1105.

4. Machida, M.; Asai, K.; Sano, M.; Tanaka, T.; Kumagai, T.; Terai, G.; Kusumoto, K. I.; Arima, T.; Akita, O.; Kashiwagi, Y.; Abe, K.; Gomi, K.; Horiuchi, H.; Kitamoto, K.; Kobayashi, T.; Takeuchi, M.; Denning, D. W.; Galagan, J. E.; Nierman, W. C.; Yu, J.; Archer, D. B.; Bennett, J. W.; Bhatnagar, D.; Cleveland, T. E.; Fedorova, N. D.; Gotoh, O.; Horikawa, H.; Hosoyama, A.; Ichinomiya, M.; Igarashi, R.; Iwashita, K.; Juvvadi, P. R.; Kato, M.; Kato, Y.; Kin, T.; Kokubun, A.; Maeda, H.; Maeyama, N.; Maruyama, J. I.; Nagasaki, H.; Nakajima, T.; Oda, K.; Okada, K.; Paulsen, I.; Sakamoto, K.; Sawano, T.; Takahashi, M.; Takase, K.; Terabayashi, Y.; Wortman, J. R.; Yamada, O.; Yamagata, Y.; Anazawa, H.; Hata, Y.; Koide, Y.; Komori, T.; Koyama, Y.; Minetoki, T.; Suharnan, S.; Tanaka, A.; Isono, K.; Kuhara, S.; Ogasawara, N.; Kikuchi, H. Nature 2005, 438, 1157.

5. Van Den Berg, M. A.; Albang, R.; Albermann, K.; Badger, J. H.; Daran, J. M.; M Driessen, A. J.; Garcia-Estrada, C.; Fedorova, N. D.; Harris, D. M.; Heijne, W. H. M.; Joardar, V.; W Kiel, J. A. K.; Kovalchuk, A.; Martín, J. F.; Nierman, W. C.; Nijland, J. G.; Pronk, J. T.; Roubos, J. A.; Van Der Klei, I. J.; Van Peij, N. N. M. E.; Veenhuis, M.; Von Döhren, H.; Wagner, C.; Wortman, J.; Bovenberg, R. A. L. Nat. Biotechnol. 2008, 26, 1161.

6. Martinez, D.; Berka, R. M.; Henrissat, B.; Saloheimo, M.; Arvas, M.; Baker, S. E.; Chapman, J.; Chertkov, O.; Coutinho, P. M.; Cullen, D.; Danchin, E. G. J.; Grigoriev, I. V.; Harris, P.; Jackson, M.; Kubicek, C. P.; Han, C. S.; Ho, I.; Larrondo, L. F.; De Leon, A. L.; Magnuson, J. K.; Merino, S.; Misra, M.; Nelson, B.; Putnam, N.; Robbertse, B.; Salamov, A. A.; Schmoll, M.; Terry, A.; Thayer, N.; Westerholm-Parvinen, A.; Schoch, C. L.; Yao, J.; Barbote, R.; Nelson, M. A.; Detter, C.; Bruce, D.; Kuske, C. R.; Xie, G.; Richardson, P.; Rokhsar, D. S.; Lucas, S. M.; Rubin, E. M.; Dunn-Coleman, N.; Ward, M.; Brettin, T. S. Nat. Biotechnol. 2008, 26, 553.

7. Martinez, D.; Larrondo, L. F.; Putnam, N.; Sollewijn Gelpke, M. D.; Huang, K.; Chapman, J.; Helfenbein, K. G.; Ramaiya, P.; Detter, J. C.; Larimer, F.; Coutinho, P. M.; Henrissat, B.; Berka, R.; Cullen, D.; Rokhsar, D. Nat. Biotechnol. 2004, 
22, 695 .

8. Martinez, D.; Challacombe, J.; Morgenstern, I.; Hibbett, D.; Schmoll, M.; Kubicek, C. P.; Ferreira, P.; Ruiz-Duenas, F. J.; Martinez, A. T.; Kersten, P.; Hammel, K. E.; Vanden Wymelenberg, A.; Gaskell, J.; Lindquist, E.; Sabat, G.; BonDurant, S. S.; Larrondo, L. F.; Canessa, P.; Vicuna, R.; Yadav, J.; Doddapaneni, H.; Subramanian, V.; Pisabarro, A. G.; Lavín, J. L.; Oguiza, J. A.; Master, E.; Henrissat, B.; Coutinho, P. M.; Harris, P.; Magnuson, J. K.; Baker, S. E.; Bruno, K.; Kenealy, W.; Hoegger, P. J.; Kües, U.; Ramaiya, P.; Lucas, S.; Salamov, A.; Shapiro, H.; Tu, H.; Chee, C. L.; Misra, M.; Xie, G.; Teter, S.; Yaver, D.; James, T.; Mokrejs, M.; Pospisek, M.; Grigoriev, I. V.; Brettin, T.; Rokhsar, D.; Berka, R.; Cullen, D. Proc. Natl. Acad. Sci. U.S.A. 2009, 106, 1954.

9. Kim, Y.; Nandakumar, M. P.; Marten, M. R. Trends Biotechnol. 2007, 25, 395.

10. Martínez, A. T.; Ruiz-Dueñas, F. J.; Martínez, M. J.; del Río, J. C.; Gutiérrez, A. Curr. Opin. Biotechnol. 2009, 20, 348.

11. Baldrian, P. FEMS Microbiol. Rev. 2006, 30, 215.

12. Brogioni, B.; Biglino, D.; Sinicropi, A.; Reijerse, E. J.; Giardina, P.; Sannia, G.; Lubitz, W.; Basosi, R.; Pogni, R. PCCP 2008, 10, 7284.

13. Rubin, E. M. Nature 2008, 454, 841.

14. Edens, W. A.; Goins, T. Q.; Dooley, D.; Henson, J. M. Appl. Environ. Microbiol. 1999, 65, 3071.

15. Iyer, G.; Chattoo, B. B. FEMS Microbiol. Lett. 2003, 227, 121.

16. Binz, T.; Canevascini, G. Curr. Microbiol. 1997, 35, 278.

17. Palonen, H.; Saloheimo, M.; Viikari, L.; Kruus, K. Enzyme Microb. Technol. 2003, 33, 854.

18. Kiiskinen, L. L.; Viikari, L.; Kruus, K. Appl. Microbiol. Biotechnol. 2002, 59, 198.

19. Thakker, G. D.; Evans, C. S.; Rao, K. K. Appl. Microbiol. Biotechnol. 1992, 37, 321.

20. Froehner, S. C.; Eriksson, K. E. J. Bacteriol. 1974, 120, 458.

21. Monteoliva, L.; Albar, J. P. Brief. Funct. Genomic. Proteomic. 2004, 3, 220.

22. Oda, K.; Kakizono, D.; Yamada, O.; Iefuji, H.; Akita, O.; Iwashita, K. Appl. Environ. Microbiol. 2006, 72, 3448.

23. Ribeiro, D. A.; Cota, J.; Alvarez, T. M.; Brüchli, F.; Bragato, J.; Pereira, B. M. P.; Pauletti, B. A.; Jackson, G.; Pimenta, M. T. B.; Murakami, M. T.; Camassola, M.; Ruller, R.; Dillon, A. J. P.; Pradella, J. G. C.; Paes Leme, A. F.; Squina, F. M. PLoS One 2012, 7.

24. Manavalan, T.; Manavalan, A.; Thangavelu, K. P.; Heese, K. J. Proteomics 2012, 77, 298.

25. Zorn, H.; Peters, T.; Nimtz, M.; Berger, R. G. Proteomics 2005, 5, 4832 .

26. Ghosh, M.; Mukherjee, R.; Nandi, B. Acta Biotechnol. 1998, 18, 243.

27. Mata, G.; Savoie, J. M. World J. Microbiol. Biotechnol. 1998, 14, 513.

28. Hori, C.; Igarashi, K.; Katayama, A.; Samejima, M. FEMS
Microbiol. Lett. 2011, 321, 14.

29. Sato, S.; Liu, F.; Koc, H.; Tien, M. Microbiology 2007, $153,3023$.

30. Wymelenberg, A. V.; Sabat, G.; Martinez, D.; Rajangam, A. S.; Teeri, T. T.; Gaskell, J.; Kersten, P. J.; Cullen, D. J. Biotechnol. 2005, 118, 17.

31. Eriksson, K. E.; Pettersson, B. Eur. J. Biochem. 1975, 51, 213.

32. Eriksson, K. E.; Pettersson, B. Eur. J. Biochem. 1975, 51, 193.

33. Streamer, M.; Eriksson, K. E.; Pettersson, B. Eur. J. Biochem. 1975, 59, 607.

34. Hao, P.; Guo, T.; Li, X.; Adav, S. S.; Yang, J.; Wei, M.; Sze, S. K. J. Proteome Res. 2010, 9, 3520.

35. Hao, P.; Qian, J.; Ren, Y.; Sze, S. K. J. Proteome Res. 2011, 10, 5568.

36. Alpert, A. J. Anal. Chem. 2008, 80, 62.

37. Adav, S. S.; Chao, L. T.; Sze, S. K. Mol. Cell. Proteomics 2012, 11.

38. Adav, S. S.; Li, A. A.; Manavalan, A.; Punt, P.; Sze, S. K. J. Proteome Res. 2010, 9, 3932.

39. Adav, S. S.; Ravindran, A.; Cheow, E. S. H.; Sze, S. K. J. Proteomics 2012, 75, 5590.

40. Adav, S. S.; Ravindran, A.; Sze, S. K. J. Proteomics 2012, 75, 1493.

41. Bantscheff, M.; Schirle, M.; Sweetman, G.; Rick, J.; Kuster, B. Anal. Bioanal. Chem. 2007, 389, 1017.

42. Xie, F.; Liu, T.; Qian, W. J.; Petyuk, V. A.; Smith, R. D. J. Biol. Chem. 2011, 286, 25443.

43. Evans, C.; Noirel, J.; Ow, S. Y.; Salim, M.; Pereira-Medrano, A. G.; Couto, N.; Pandhal, J.; Smith, D.; Pham, T. K.; Karunakaran, E.; Zou, X.; Biggs, C. A.; Wright, P. C. Anal. Bioanal. Chem. 2012, 404, 1011.

44. Noire, J.; Evans, C.; Salim, M.; Mukherjee, J.; Ow, S. Y.; Pandhal, J.; Pham, T. K.; Biggs, C. A.; Wright, P. C. Curr. Proteomics 2011, 8, 17.

45. Thompson, A.; Schäfer, J.; Kuhn, K.; Kienle, S.; Schwarz, J.; Schmidt, G.; Neumann, T.; Hamon, C. Anal. Chem. 2003, 75, 1895.

46. Adav, S. S.; Ng, C. S.; Arulmani, M.; Sze, S. K. J. Proteome Res. 2010, 9, 3016.

47. Le Crom, S.; Schackwitz, W.; Pennacchio, L.; Magnuson, J. K.; Culley, D. E.; Collett, J. R.; Martin, J.; Druzhinina, I. S.; Mathis, H.; Monot, F.; Seiboth, B.; Cherry, B.; Rey, M.; Berka, R.; Kubicek, C. P.; Baker, S. E.; Margeot, A. Proc. Natl. Acad. Sci. U. S. A. 2009, 106, 16151.

48. Manavalan, A.; Adav, S. S.; Sze, S. K. J. Proteomics 2011, 75,642 .

49. Wymelenberg, A. V.; Gaskell, J.; Mozuch, M.; Sabat, G.; Ralph, J.; Skyba, O.; Mansfield, S. D.; Blanchette, R. A.; Martinez, D.; Grigoriev, I.; Kersten, P. J.; Cullen, D. Appl. Environ. Microbiol. 2010, 76, 3599.

50. Wu, W. W.; Wang, G.; Baek, S. J.; Shen, R. F. J. Proteome Res. 2006, 5, 651 .

51. Chee, S. G.; Poh, K. C.; Trong, K. P.; Wright, P. C. J. Proteome Res. 2007, 6, 821 . 
52. Karp, N. A.; Huber, W.; Sadowski, P. G.; Charles, P. D.; Hester, S. V.; Lilley, K. S. Mol. Cell. Proteomics 2010, 9, 1885.

53. Patel, V. J.; Thalassinos, K.; Slade, S. E.; Connolly, J. B.; Crombie, A.; Murrell, J. C.; Scrivens, J. H. J. Proteome Res. 2009, 8, 3752.

54. Pierce, A.; Unwin, R. D.; Evans, C. A.; Griffiths, S.; Carney, L.; Zhang, L.; Jaworska, E.; Lee, C. F.; Blinco, D.; Okoniewski, M. J.; Miller, C. J.; Bitton, D. A.; Spooncer, E.; Whetton, A. D. Mol. Cell. Proteomics 2008, 7, 853.

55. Bantscheff, M.; Boesche, M.; Eberhard, D.; Matthieson, T.; Sweetman, G.; Kuster, B. Mol. Cell. Proteomics 2008, 7, 1702.

56. Köcher, T.; Pichler, P.; Schutzbier, M.; Stingl, C.; Kaul, A.; Teucher, N.; Hasenfuss, G.; Penninger, J. M.; Mechtler, K. J. Proteome Res. 2009, 8, 4743.

57. Wang, H.; Alvarez, S.; Hicks, L. M. J. Proteome Res. 2012, $11,487$.

58. Griffin, T. J.; Xie, H.; Bandhakavi, S.; Popko, J.; Mohan, A.; Carlis, J. V.; Higgins, L. J. Proteome Res. 2007, 6, 4200.

59. Dayon, L.; Pasquarello, C.; Hoogland, C.; Sanchez, J. C.; Scherl, A. J. Proteomics 2010, 73, 769.

60. Olsen, J. V.; Macek, B.; Lange, O.; Makarov, A.; Horning, S.; Mann, M. Nat. Methods 2007, 4, 709.

61. Swaney, D. L.; McAlister, G. C.; Wirtala, M.; Schwartz, J. C.; Syka, J. E. P.; Coon, J. J. Anal. Chem. 2007, 79, 477.

62. Shirran, S. L.; Botting, C. H. J. Proteomics 2010, 73, 1391.

63. Onsongo, G.; Stone, M. D.; Van Riper, S. K.; Chilton, J.; Wu, B.; Higgins, L.; Lund, T. C.; Carlis, J. V.; Griffin, T. J. Proteomics 2010, 10, 3533.

64. Christoforou, A. L.; Lilley, K. S. Anal. Bioanal. Chem. 2012, 404, 1029.
65. Ong, S. E.; Blagoev, B.; Kratchmarova, I.; Kristensen, D. B.; Steen, H.; Pandey, A.; Mann, M. Molecular \& Cellular Proteomics: MCP 2002, 1, 376.

66. Tian, C.; Beeson, W. T.; Iavarone, A. T.; Sun, J.; Marletta, M. A.; Cate, J. H. D.; Glass, N. L. Proc. Natl. Acad. Sci. U.S.A. 2009, 106, 22157.

67. Phillips, C. M.; Iavarone, A. T.; Marletta, M. A. J. Proteome Res. 2011, 10, 4177.

68. Kota, U.; Goshe, M. B. Phytochemistry 2011, 72, 1040.

69. Washburn, M. P.; Wolters, D.; Yates, J. R. Nat. Biotechnol. 2001, 19, 242.

70. Yao, X.; Freas, A.; Ramirez, J.; Demirev, P. A.; Fenselau, C. Anal. Chem. 2001, 73, 2836.

71. Gygi, S. P.; Rist, B.; Gerber, S. A.; Turecek, F.; Gelb, M. H.; Aebersold, R. Nat. Biotechnol. 1999, 17, 994.

72. Ishihama, Y.; Oda, Y.; Tabata, T.; Sato, T.; Nagasu, T.; Rappsilber, J.; Mann, M. Mol. Cell. Proteomics 2005, 4, 1265.

73. Matzke, M. M.; Brown, J. N.; Gritsenko, M. A.; Metz, T. O.; Pounds, J. G.; Rodland, K. D.; Shukla, A. K.; Smith, R. D.; Waters, K. M.; McDermott, J. E.; Webb-Robertson, B. J. Proteomics 2012.

74. Tang, K.; Page, J. S.; Smith, R. D. J. Am. Soc. Mass Spectrom. 2004, 15, 1416.

75. Chelius, D.; Bondarenko, P. V. J. Proteome Res. 2002, 1, 317.

76. Adav, S. S.; Cheow, E. S. H.; Ravindran, A.; Dutta, B.; Sze, S. K. J. Proteomics 2012, 75, 3694.

77. Adav, S. S.; Ravindran, A.; Chao, L. T.; Tan, L.; Singh, S.; Sze, S. K. J. Proteome Res. 2011, 10, 4579.

78. Gerber, S. A.; Rush, J.; Stemman, O.; Kirschner, M. W.; Gygi, S. P. Proc. Natl. Acad. Sci. U.S.A. 2003, 100, 6940. 